\title{
CATALYTIC CARBON MONOXIDE IN THE INDUSTRIAL GAS EMISSIONS
}

\author{
Kuznyetsov S.I., Maljejev V.O., Bezpalchenko V.M., Dibolsky S.A. \\ Kherson National Technical University \\ Beryslavske highway, 24, 73008, Kherson \\ ksieko@rambler.ru,mahnoveccs@gmail.com, \\ mahnoveccs@gmail.com,dibserj@gmail.com
}

\begin{abstract}
A new method for the catalytic neutralization of carbon monoxide has been developed. The composition of the highly efficient $\mathrm{Zn}-\mathrm{Cu}-\mathrm{Cr}$ pumice concrete catalyst and the method of its application to tubular supports are synthesized. When studying the kinetics of the reaction, the main parameters (temperature coefficient, reaction order, equilibrium constant) are determined and investigated that allow a complete comprehensive assessment of the developed catalysts. Experimental data show that the catalyst begins to show activity at a temperature of $\mathrm{t}=150^{\circ} \mathrm{C}$. With increasing temperature, the degree of conversion increases, reaching maximum values (86-96\%) at a gas and space velocity of 10000-20000 $\mathrm{h}^{-1}$. A further increase in temperature does not lead to a noticeable increase in the degree of conversion, since a residual concentration of carbon monoxide close to equilibrium is established in the gas mixture, the value of which depends on temperature. Due to the fact that the reaction is exothermic, the temperature in the reactor can increase, reaching a critical value. Studies have shown that when the reactor is heated to $350-400^{\circ} \mathrm{C}$, a further spontaneous increase in temperature is observed. It follows from this that the initial gas temperature should not be higher than critical. Long-term operation of the catalyst in laboratory conditions showed that its activity within 70 hours of continuous operation did not change. Water vapor present in the gas does not reduce the activity of the proposed catalyst. The synthesized catalyst exhibits higher activity than industrial low-temperature catalyst. The design of the apparatus, a tubular reactor, in which the catalytic treatment of industrial waste gases contaminated with carbon monoxide is carried out, has been developed and tested. Key words: neutralization of carbon monoxide, pumice concrete, tubular reactor.
\end{abstract}

Каталітична нейтралізація монооксиду карбону в промислових газових викидах. Кузнсцов С.I., Малєєв В.О., Безпальченко В.М., Дібольский С.А. Розроблено новий метод каталітичної нейтралізації монооксиду карбону. Синтезовано склад високоефективного $\mathrm{Zn}-\mathrm{Cu}-\mathrm{Cr}$ каталізатора-пемзобетона та спосіб його нанесення на трубчасті носії. При вивченні кінетики реакції визначені й досліджені основні параметри (температурний коефіцієнт, порядок реакції, константа швидкості), які дозволяють надати повну комплексну оцінку розробленим каталізаторам. Експериментальні дані показують, що каталізатор починає проявляти активність при температурі $150^{\circ} \mathrm{C} .3$ підвищенням температури ступінь перетворення збільшується, досягаючи максимальних значень (86-96\%) при температурі $300^{\circ} \mathrm{C}$ та об'ємній швидкості газу 10000-20000 год ${ }^{-1}$. Подальше збільшення температури не призводить до суттєвого зростання ступеня перетворення, тому що в газовій суміші встановлюється близька до рівноважної залишкова концентрація монооксиду карбону, величина якої залежить від температури. 3 огляду на те, що реакція екзотермічна, температура в реакторі може зростати, досягаючи критичного значення. Дослідження показали, що при розігріві реактора до $350-400{ }^{\circ} \mathrm{C}$ спостерігається подальше неконтрольоване підвищення температури. Тому початкова температура газу не повинна бути вище критичної. Тривала експлуатація каталізатора в лабораторних умовах показала, що його активність в межах 70 годин безперервної роботи не змінювалася. Наявність у газі водяної пари не знижує активність запропонованого каталізатора. Синтезований каталізатор проявляє більш високу активність ніж промисловий низькотемпературний каталізатор НТК-4. Розроблена і випробувана конструкція апарату - трубчастого реактора, в якому здійснюється каталітичне очищення промислових газів, забруднених монооксидом карбону. Ключові слова: нейтралізація монооксиду карбону, каталізатор-пемзобетон, трубчастий реактор.

Problem statement. It is known that human body passes through the lungs about $20 \mathrm{~m}^{3}$ of air a day, and during the whole life this number is about $600000 \mathrm{~m}^{3}$. It is obvious that air pollution, even in small doses can make serious damage to health.

Nowadays in the MAC data there are more than 4.5 thousand harmful air pollutants and carbon monoxide has a leading position in this list. Its global emissions account is 177 million tons per year. The main source of carbon monoxide formation is the heat power industry. This gas is 300 times faster soluble in blood than oxygen and its concentration in air of more than $0.1 \%$ is lethal for man. It takes three to six months for carbon monoxide to become carbon dioxide,
The purpose of this study was to develop new types of catalysts and equipment for the effective neutralization of carbon monoxide included in the exhaust gas heat energy and industrial facilities. Now the combustion products are emitted into the atmosphere without treatment, and large volumes of flue gases and the presence in their structure of associated impurities, such as dust and sulfur dioxide complicates process of gases neutralization.

Actualization. Development of new catalysts - one of the possible solutions for this problem. Catalytic methods have a number of significant advantages over other methods of sanitary cleaning of gases, however, this requires the availability of cheap and effective cata- 
lysts. Mass production of the catalysts is only possible if raw materials used are available and of low cost.

From the experience of using catalysts for final oxidation of carbon monoxide it is known that as the catalytically active substances can be used compounds of $\mathrm{Cu}, \mathrm{Cr}, \mathrm{Fe}, \mathrm{Mn}, \mathrm{Pt}, \mathrm{Ag}, \mathrm{Sn}, \mathrm{Co}, \mathrm{Pd}, \mathrm{Zn}, \mathrm{Cd}$, Th, Be, et al. To obtain the catalysts it's necessary to impregnate a porous carrier with catalytically active substances. Then, the filler is added, and residue, drying and tableting the resulting mixture is held. However, the catalysts obtained by the described technologies are expensive and have limited amounts of release, therefore, it can not be recommended for sanitary cleaning of large volumes of gas.

These studies have led to the development of catalysts for the new types of neutralization carbon monoxide. They have a high level of productivity, activity, selectivity, mechanical strength and heat resistance, low poisoning and low aerodynamic resistance. To form the contact mass cheap and available substances are used.

Novelty. The most highly active catalysts are shown having the following composition: $\mathrm{ZnO}-2 \%, \mathrm{CuO}-8 \%$, $\mathrm{Cr}_{2} \mathrm{O}_{3}-6 \%$.

The weight ratios of catalytically active substance, aluminum powder and cement 1: 2.5: 3 .

The manufacturing method of the catalyst is a mixture of catalytically active substances and aluminum metal (powder), ammonia water and cement. The porous structure of the catalyst is formed by reacting of the intensive flowing ammonia water with aluminum metal and the catalytically active substances, resulting in foaming of the reactants. The catalyst mass in a pasty state is applied to the inner surface of pipe with a punch.

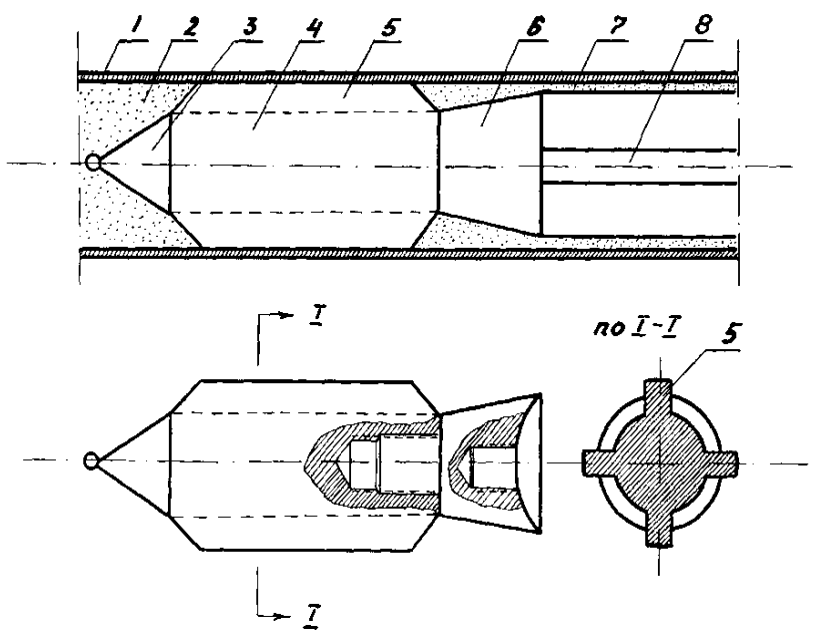

Fig. 1. Applying of catalyst device on the inner surface of pipes: 1 - pipe; 2 -catalyst mass;

3 - punch head; 4 - punch body; 5 - guide ribs; 6 -gauge skirt; 7 - supported catalyst layer; 8 - rod

Once hardened, the contact mass is dried and calcined at $350^{\circ} \mathrm{C}$ temperature. The resulting composition forms a solid porous layer inside the pipes - pumice concrete.
The pipes are mounted on the tube sheets and placed in a common housing forming a tubular reactor.

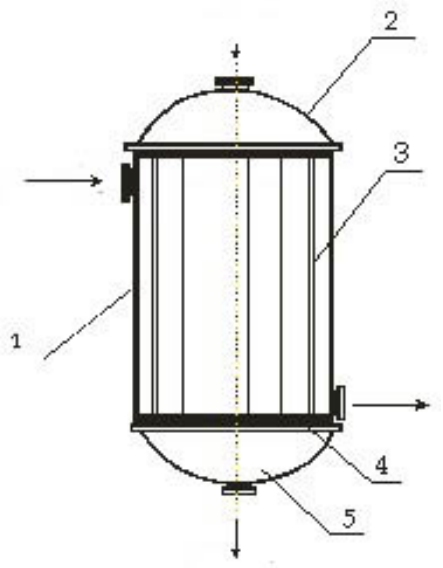

Fig. 2. The tubular reactor: 1 -case; 2 -cover, 3 -tube catalyst; 4 -tube sheet; 5 -bottom

Experimental data shows that the catalyst starts to be active at $\mathrm{t}=150^{\circ} \mathrm{C}$. With increasing temperature, the degree of conversion increases, reaching a maximum at gas velocity $10000-20000 \mathrm{~h}^{-1}$ is $86-96 \%$. Followed temperature increasing does not lead to a marked increase in the degree of conversion, because in the gas mixture is set close to the equilibrium concentration of the residual carbon monoxide which value depends on the temperature.

Since the reaction is exothermic, the reactor temperature may rise, reaching critical point. Studies showed that on heating the reactor to $350-400^{\circ} \mathrm{C}$ followed spontaneous temperature rises. It means that the initial gas temperature should not be above the critical value defined by the formula:

$$
t_{\text {init }} \leq t_{\text {crit }}-\Delta t
$$

where: $t_{\text {crit }}-$ the critical temperature in the reactor $\left(\mathrm{t}=350^{\circ} \mathrm{C}\right)$;

$\Delta t$ - the temperature rise in the reactor due to the heat of reaction, ${ }^{\circ} \mathrm{C}$

$$
\Delta t=\frac{Q \cdot C_{C O} \cdot 1000}{100 \cdot 22.4 \cdot C_{p} \cdot \rho},
$$

where: $\mathrm{Q}$ - heat of reaction, $\mathrm{kJ} / \mathrm{mol}$;

$C_{C O}-\mathrm{CO}$ content of the gas, $\%$ (vol.);

$C_{p}$ - specific heat of gas, $\mathrm{kJ} / \mathrm{kg} \cdot \mathrm{deg}$;

$\rho$ - gas density $\mathrm{kg} / \mathrm{m}^{3}$.

From the formula given above, it follows that for every percentage entered into the carbon monoxide reaction gas mixture temperature will rise $\Delta t=\frac{41 \cdot 1 \cdot 1000}{100 \cdot 22.4 \cdot 1.02 \cdot 1.29}=13.9^{\circ} \mathrm{C}$, consequently: $t_{\text {init }} \leq t_{\text {crit }}-13.9 \cdot C_{C O}$.

The exhaust gases of several industries, in addition to carbon monoxide in its composition contain sulfur compounds, dust and other impurities. In this regard, it is reasonable to study the influence of these impurities on the catalyst activity. 
It is known that the presence in the gas of $0.1 \%$ after 10 hours, the catalyst begins to show signs of decreased activity. After 20 hours, the degree of purification, decreases from $90 \%$ to $75 \%$ and in 70 hours $-43 \%$. This is an indication of "poisoning" of the catalyst.

The slower fall in activity is observed in the presence of dust in the cleaned gases. After 70 hours of continuous operation the activity of the catalyst is reduced by $10 \%$ in the presence of gas in $3-5 \mathrm{~g} / \mathrm{m}^{3}$ of dust. Dust causes a temporary decrease in the catalyst activity due to its mechanical clogging. Removing dust from the reaction zone restored the catalyst activity completely.

Continuous operation of the catalyst in the laboratory showed that its activity within 70 hours of continuous operation does not change. Water vapor in the gas don't not reduce catalyst activity. The synthesized catalyst shows higher activity than the commercial low-temperature catalyst LTC-4.

The main parameters that allow you to complete a comprehensive assessment of the developed catalysts have been identified in the study of reaction kinetics. These include temperature coefficient, reaction order, and rate constant.

The relatively low values of the temperature coefficient and the activation energy leads to the conclusion that the oxidation reaction of carbon monoxide on the catalyst takes place in the diffusion region. This is evidenced by the first-order reaction. Moreover, the excess oxygen at the process rate is limited by diffusion of carbon monoxide in the catalyst pores. It is assumed that the conversion of one broken-bond in the molecule and $\mathrm{CO}$ connection between hydrogen and oxygen in the water molecule. The total energy breaks the bonds is $1178 \mathrm{~kJ} / \mathrm{mol}$, which virtually eliminates leakage without a catalyst reaction. In catalytic reacting carbon oxide consuming oxygen from the catalyst, and the water returns the catalyst, both processes occur simultaneously. The reaction mechanism fused interaction leads to a considerable reduction of the energy barrier. This allows the process at relatively low temperatures and high space velocities, as observed in the present studies. The most effective means of accelerating the processes occurring in the diffusion region (internal transfer), is to reduce the grain size of the catalyst, as well as the use of catalysts with high surface area, in which the pores are large transport routes to the surface of the highly produced fine pores of small length.

The theoretical time necessary for the diffusion of carbon monoxide in the catalyst pores is determined by Einstein formula;

$$
\tau_{d}=\frac{L^{2}}{2 D_{e}}
$$

where: $\mathrm{L}$ - penetration depth (grain radius), $\mathrm{cm}$;

$D_{e}-$ the effective diffusion coefficient.

The mean free path of molecules of CO $(58 \mathrm{~nm})$, far smaller than the diameter of the catalyst $(3000 \mathrm{~nm})$, the diffusion coefficient in the operating conditions given by Arnold.

$$
D_{e}=\frac{0.00837 \cdot T^{5 / 2} \cdot \sqrt{\frac{1}{M_{A}}+\frac{1}{M_{A}}}}{P \cdot\left(V_{A}^{1 / 3}+V_{B}^{1 / 3}\right)^{2} \cdot\left(T+C_{A+B}\right)},
$$

where: $M_{A}, M_{B}$ - the molar mass of the components, $\mathrm{g} / \mathrm{mol}$;

$V_{A}, V_{B}$ - molar volume of the components $\mathrm{cm}^{3} / \mathrm{mol}$;

$\mathrm{T}$ - temperature boiling components $\mathrm{K}$;

$\mathrm{P}$ - pressure, $\mathrm{MPa}$;

$C_{A+B}-$ constant Sutherland.

$$
C_{A+B}=1.47 \cdot \phi \cdot\left(T_{A} \cdot T_{B}\right)^{0.5}
$$

where: $V_{A}, V_{B}$ - boiling point components ${ }^{\circ} \mathrm{K}$.

$$
\phi=8 \frac{\left(V_{A} \cdot V_{B}\right)^{0.5}}{V_{A}+V_{B}}
$$

Substituting the values of the operating parameters of the equation, we obtain:

$$
\begin{gathered}
\phi=8 \frac{(30.7 \cdot 29.9)^{0.5}}{30.7+29.9}=3,999 ; \\
C_{A+B}=1,47 \cdot 3.999 \cdot(68 \cdot 60)^{0.5}=375,49 ; \\
D_{e}=\frac{0.00837 \cdot 523^{5 / 2} \cdot \sqrt{\frac{1}{28}+\frac{1}{28.9}}}{1 \cdot\left(30.7^{1 / 3}+29,9^{1 / 3}\right)^{2} \cdot(523+375.49)}= \\
=0,397 \mathrm{~cm}^{2} / \mathrm{s}
\end{gathered}
$$

Then, according to the equation:

$$
\tau_{d}=\frac{0.5}{2 \cdot 0.397}=0,315 s
$$

In view of this time we define theoretically allowable space velocity:

$$
W=\frac{3600}{\tau_{d}}=\frac{3600}{0.315}=11428 h^{-1}
$$

If you do not use a large three-dimensional velocity of the gas, the degree of conversion of $\mathrm{CO}$ will be reduced by minimizing the using of inner surface of the catalyst. The bulk gas velocity can be increased by using a smaller catalyst pellet, but this increases the flow resistance layer. The equilibrium conversion rate is determined from the relationship:

$$
K_{p}=\frac{\left[P_{\mathrm{CO}}\right] \cdot\left[P_{\mathrm{H}_{2} \mathrm{O}}\right]}{\left[P_{\mathrm{CO}}\right] \cdot\left[P_{\mathrm{H}_{2}}\right]},
$$

where: $K_{p}-$ the equilibrium constant;

$P_{\mathrm{CO}}, P_{\mathrm{H}_{2} \mathrm{O}}, P_{\mathrm{CO}_{2}}, P_{\mathrm{H}_{2}}$ - the partial pressure of the components at the time of equilibrium.

Expressing partial pressures through the initial concentration of the components in the feed gas, we obtain: 
Active zinc-copper-chromium catalysts - pumice concrete

\begin{tabular}{|c|c|c|c|c|c|c|}
\multicolumn{7}{|c|}{$\left(\mathrm{ZnO}-2 \% ; \mathrm{Cr}_{2} \mathrm{O}_{3}-6 \% ; \mathrm{CuO}-8 \% ; t=300^{\circ} \mathrm{C}\right)$} \\
\hline \multirow{2}{*}{$\begin{array}{c}\text { Space velocity, } \\
h^{-1}\end{array}$} & \multicolumn{2}{|c|}{ CO content, $\%$} & \multirow{3}{*}{ Conversion, $\%$} & \multicolumn{3}{c|}{ Catalyst activity } \\
\cline { 2 - 6 } & Entrance & Exit & & $\begin{array}{c}\mathrm{VCA} \\
\mathrm{kg} / \mathrm{m}^{3} \cdot \mathrm{h}\end{array}$ & $\begin{array}{c}\mathrm{MCA} \\
\mathrm{kg} / \mathrm{kg} \cdot \mathrm{h}\end{array}$ & $\begin{array}{c}\mathrm{SCA} \\
\mathrm{kg} / \mathrm{m}^{2} \cdot \mathrm{h}\end{array}$ \\
\hline 5000 & 2,0 & 0,08 & 96 & 120 & 0,092 & 9,2 \\
\hline 10000 & 2,0 & 0,12 & 94 & 235 & 0,18 & 18 \\
\hline 15000 & 2,0 & 0,2 & 90 & 337,5 & 0,259 & 25 \\
\hline 20000 & 2,0 & 0,28 & 86 & 430 & 0,330 & 33 \\
\hline 25000 & 2,0 & 0,44 & 78 & 487,5 & 0,375 & 37,5 \\
\hline
\end{tabular}

$$
\begin{aligned}
P_{\mathrm{CO}}=\frac{a-a \cdot X_{p}}{1+n} \cdot p & P_{\mathrm{H}_{2} \mathrm{O}}=\frac{n-a \cdot X_{p}}{1+n} \cdot p \\
P_{\mathrm{H}_{2}}=\frac{b-a \cdot X_{p}}{1+n} \cdot p & P_{\mathrm{CO}_{2}}=\frac{c-a \cdot X_{p}}{1+n} \cdot p,
\end{aligned}
$$
gas;

where: a, b, c $-\mathrm{CO}, \mathrm{H}_{2}, \mathrm{CO}_{2}$ respectively, in the feed

$\mathrm{n}$ - the ratio of the vapor-gas;

$X_{p}$ - the equilibrium degree of conversion.

Substituting the values of the partial pressures of the components in the equation, we obtain:

$$
K_{P}=\frac{\left(a-a \cdot X_{p}\right) \cdot\left(n-a \cdot X_{p}\right)}{\left(c+a \cdot X_{p}\right) \cdot\left(b+a \cdot X_{p}\right)}
$$

Solving this equation for, $X_{P}$ we find:

$$
\begin{gathered}
X_{p}=\frac{-a \cdot\left(K_{p} b+K_{p} c+a+n\right)}{2 \cdot a^{2} \cdot\left(K_{p}-1\right)} \pm \\
\pm \frac{\sqrt{\left[a \cdot\left(K_{p} b+K_{p} c+a+n\right)\right]^{2}-4 a^{2} \cdot\left(K_{p}-1\right) \cdot\left(K_{p} b c-a n\right)}}{2 \cdot a^{2} \cdot\left(K_{p}-1\right)}
\end{gathered}
$$

In our case: $\mathrm{a}=0.02 ; \mathrm{B}=0 ; \mathrm{c}=0 ; \mathrm{n}=1,9$.

The equilibrium constant for a given by:

$$
\begin{gathered}
X_{p}=\frac{-0,02 \cdot(0.02+1.9)}{2 \cdot 0,02^{2} \cdot(0.02459-1)} \pm \\
\pm \frac{\sqrt{[0.02 \cdot(0.02+1.9)]^{2}-4 \cdot 0.02^{2} \cdot(0.02459-1) \cdot(-0.02 \cdot 1.9)}}{2 \cdot 0.02^{2} \cdot(0,02459-1)}= \\
=97.43 \%
\end{gathered}
$$

The maximum conversion rate in the diffusion region is $90-93.5 \%$, which is $92-96 \%$ of the theoretical.

For tubular reactors designed activity investigated catalysts per unit volume (volume of the catalytic activity VCA), a unit of mass (the mass of the catalytic activity MCA) and the specific surface of the catalyst (surface catalytic activity SCA). The determination of these values is carried out according to the formulas:

$$
\begin{gathered}
\mathrm{VCA}=\frac{\mathrm{G}_{\mathrm{n}}}{\mathrm{V}_{\text {cat }} \cdot \tau}=\frac{\mathrm{W}_{\mathrm{r}} \cdot \mathrm{C}_{\mathrm{co}}^{\mathrm{en}} \cdot \mathrm{M}}{100 \cdot 22.4} \cdot \alpha \mathrm{\kappa g} / \mathrm{m}^{3} \cdot \mathrm{h} ; \\
\mathrm{MCA}=\frac{\mathrm{G}_{\mathrm{n}}}{\mathrm{g}_{\text {cat }} \cdot \tau}=\frac{\mathrm{VCA}}{\rho} \mathrm{\kappa g} / \mathrm{Kg} \cdot \mathrm{h} ; \\
\mathrm{SCA}=\frac{\mathrm{G}_{\mathrm{n}}}{\mathrm{S}_{\text {cat }} \cdot \tau}=\frac{\mathrm{MCA}}{\mathrm{S}_{\text {cat }} \cdot 1000} \mathrm{Kg} / \mathrm{m}^{2} \cdot \mathrm{h}
\end{gathered}
$$

where: $G_{n}$ - the mass of CO oxidation, $\mathrm{kg}$;

$V_{c a t}$ - the volume of catalyst, $\mathrm{m}^{3}$;

$g_{\text {cat }}$ - the mass of the catalyst, $\mathrm{kg}$;

$S_{\text {cat }}$ - catalyst surface, $\mathrm{m}^{2} / \mathrm{g}$;

$\tau$ - reaction time, $\mathrm{h}$;

$W g$ - hourly space velocity, $\mathrm{h}^{-1}$;

$C_{c o}^{e n}-\mathrm{CO}$ concentration at the reactor inlet, \% (vol.);

$\mathrm{M}$ - molecular mass of $\mathrm{CO}$;

$\alpha$ - the conversion of $\mathrm{CO}$, the proportion of units;

$\rho$ - density of the gas $\mathrm{kg} / \mathrm{m}^{3}$.

The tubular reactor has a high capacity, can handle dusty gases and provides a high degree of purification, without requiring a large operating costs.

\section{References}

1. Patent of invention UKRAINE UA 62855A, IPC 7 V01D47 / 00, C10K1 / 00. Way of cleaning exhausted gases of boiler houses from oxide of carbon and device for doing it. / Kuznyetsov S.I. (UKRAINE; Zayavl.04.09.03; Publ. 15.12.03, Bul. № 12, 2003.

2. Patent of invention UKRAINE UA 62856A, IPC 7B01D47 / 00, B01D47 / 08, C10K1 / 00, C10K1 / 34. Way of cleaning exhausted gases of boiler houses in textile industries / Kuznyetsov S.I. (UKRAINE); Stated. 04.09.03; Publ. 15.12.03. Bull. № 12, 2003.

3. Patent of invention №67180 MKB F23J11 / 00. Device for cleaning and heat recycling of exhausted gases / Mikhailik V.D., Mikhailik S.V. Kuznyetsov S.I. HDTU., Bull. № 6, 2004. 


\title{
ЗНИХЕННЯ ВИНОСУ IОНІВ ЦИНКУ I НIКЕАЮ ПРОМИВНИМИ ВОДАМИ ГААЬВАНІЧНИХ АІНІЙ З УТИАІЗАЦІЕЮ У ВИГАЯДІ ДОДАТКОВИХ ШАРIB ПOКРИТТIВ
}

\author{
Майзеліс А.O. \\ Національний технічний університет \\ «Харківський політехнічний інститут» \\ вул. Кирпичова, 2, 61002, м. Харків \\ a.maizelis@gmail.com
}

\begin{abstract}
Представлено результати дослідження умов зниження виносу іонів цинку і нікелю промивними водами гальванічних ліній цинкування і електроосадження мультишарових $(\mathrm{Zn}-\mathrm{Ni})_{1} /(\mathrm{Zn}-\mathrm{Ni})_{2}$ покриттів з утилізацією металів у тих же лініях. Показано, що використання додаткової гальванічної ванни з розведеним за іонами металів електролітом дає змогу залежно від складу електроліту цинкування у 3-10 разів знизити винос іонів металів у систему промивних вод лінії. Завдяки використанню комплексного гліцинатно-аміакатного розчину в цій ванні на оцинкованій поверхні осаджується якісний додатковий шар сплаву, який захищає iї від корозії. Це дає змогу не використовувати для такого захисту хроматну пасивацію цинкових покриттів у розчині, що містять токсичні сполуки $\mathrm{Cr}(\mathrm{VI})$. В гальванічній лінії електроосадження мультишарового покриття, у якому періодично чергуються тонкі шари сплавів Zn-Ni різного складу, запропоновано утилізувати метали у вигляді підшару сплаву Zn-Ni, що збагачений за цинком для розширення сфери використання покриттів. Такий підшар осаджують у додатковій ванні з розведеним пірофосфатно-цитратним розчином, завдяки чому на порядок зменшується винос іонів металів у промивні води лінії. У схемі запропоновано також повернення основного ліганду (пірофосфату) електроліту, який виноситься деталями під час промивання в робочу ванну. Результати дослідження можуть бути використані в гальванічних ділянках і цехах, в яких здійснюється електроосадження цинку з будь-яких електролітів, для позбавлення операції хроматної пасивації у розчинах, що містять сполуки $\mathrm{Cr}(\mathrm{VI})$, а також на тих підприємствах, де $є$ потреба в захисті сталевої поверхні на рівні кадмієвих покриттів без використання токсичних іонів кадмію, завдяки високій корозійній стійкості мультишарових $(\mathrm{Zn}-\mathrm{Ni})_{1} /(\mathrm{Zn}-\mathrm{Ni})_{2}$ покриттів. Ключові слова: сплав цинк-нікель, промивні води, комплексні електроліти, утилізація металів, винос електроліту.
\end{abstract}

Reduction of zinc and nickel ion loss by rinsing waters of galvanic lines with their utilization in the form of additional coating layers. Maizelis A.

The results of the study of the conditions for reducing the loss of zinc and nickel ions by the rinsing waters of galvanic lines of zing coating deposition and electrodeposition of $(\mathrm{Zn}-\mathrm{Ni})_{1} /(\mathrm{Zn}-\mathrm{Ni})_{2}$ multilayer coatings with metal utilization in the same lines are presented. It is shown that the use of an additional galvanic bath with low-concentrated electrolyte, depending on the composition of the electrolyte for zinc electrodepostion, can reduce the loss of metal ions into the rinsing water system of the line by 3-10 times. Due to the use of a complex glycinate-ammonia solution in this bath, a high-quality additional alloy layer is deposited on the surface of zinc coating, which protects it from corrosion. This avoids the use of chromatic passivation of zinc coatings in solution that produces toxic $\mathrm{Cr}$ (VI) compounds for such protection. In the galvanic line of the electrodeposition of multilayer coating consisting of periodically alternate thin layers of $\mathrm{Zn}-\mathrm{Ni}$ alloys of different composition, it is proposed to utilize metals in the form of a $\mathrm{Zn}$-Ni alloy sublayer enriched with zinc to expand the scope of the coatings. This sublayer is deposited in an additional low-concentrated bath with pyrophosphate-citrate solution, leading to the reduce in metal ions loss into the rinsing waters of line by an order. The scheme also proposes the return of the main ligand (pyrophposphate) of the electrolyte, which is carried out by washing the parts, into the working bath. The results of the study can be used in galvanic lines and workshops in which zinc is deposited from any electrolyte to get rid of the operation of chromatic passivation in solutions containing $\mathrm{Cr}$ (VI) compounds, as well as in those enterprises where steel protection is required at the level of cadmium coatings without the use of toxic cadmium ions due to the high corrosion resistance of $(\mathrm{Zn}-\mathrm{Ni})_{1} /(\mathrm{Zn}-\mathrm{Ni})_{2}$ multilayer coatings. Key words: zinc-nickel alloy, rinsing water, complex electrolytes, metal utilization, electrolyte loss.

Постановка проблеми. Гальванічні покриття один із найдешевших і найпростіших способів модифікації поверхні з метою надання їй покращених фізико-хімічних і механічних властивостей. Водночас у лініях гальванічного нанесення покриттів генерується досить велика кількість стоків, що містить іони металів, оскільки в системи промивання $з$ деталями виноситься концентрований електроліт.

Цинкові покриття захищають сталеві вироби від корозії завдяки своєму більш негативному потенціалу в багатьох середовищах. Тому покриття $\epsilon$ анодним щодо стальних деталей і захищає їх завдяки своєму розчиненню. Для зниження швидкості корозії цинкових покриттів їх пасивують. Найбільш широко поширене в промисловості хроматування, в процесі якого використовуються токсичні сполуки $\mathrm{Cr}(\mathrm{VI})$, від яких необхідно знешкоджувати не тільки промивні води, але й концентровані відпрацьовані розчини.

Покриття сплавом Zn-Ni мають антикорозійні властивості, що відрізняються як від цинкових 
покриттів, які захищають сталеві деталі анодно, так і від нікелевих, які є більш корозійно стійкими, ніж цинкові $[1 ; 2]$. Корозійна стійкість покриттів сплавом цинк-нікель близька до кадмієвих, що дає змогу під час заміни ними кадмієвих покриттів прибрати зі стоків гальванічних цехів токсичні іони $\mathrm{Cd}^{2+}$. У свою чергу, корозійна стійкість покриттів сплавом $\mathrm{Zn}-\mathrm{Ni}$ залежить від елементного та фазового їхнього складу, а також від структури. Склад і структура покриття визначаються умовами їх електроосадження, передусім типом електроліту та параметрами електролізу під час його використання. Найбільш високу корозійну стійкість мають мультишарові покриття, що складаються 3 тонких шарів сплавів $\mathrm{Zn}-\mathrm{Ni}$, що чергуються.

Однак і після заміни операцій із використанням токсичних сполук $\mathrm{Cr}$ (VI) і Cd (II) залишається необхідність у знешкодженні стічних вод гальванічних ліній як цинкування, так і електроосадження сплаву цинк-нікель. Наприклад, підвищення концентрації іонів нікелю у водоймах спочатку призводить до загибелі водоростей, а за подальшого підвищення концентрації - навіть до загибелі риб. Підвищення концентрації іонів нікелю у грунті призводить до затримки росту культурних рослин. Вплив на людину у малих концентраціях полягає в прояві алергічних реакцій, дерматиту, у великих концентраціях - у порушенні обміну речовин, порушенні функції нирок. С дані про онкологічну небезпеку іонів нікелю.

Тому підприємства мають станції нейтралізації сумарних стічних вод цеху, вартість обслуговування яких $є$ суттєвим складником у сумарній вартості нанесення покриття. Отже, зниження навантаження на ці системи очищення є достатнім економічним стимулом для впровадження нових технологій.

Частково окупити витрати на знешкодження дають змогу локальні схеми вилучення іонів металів із промивних вод окремих гальванічних ліній. Електролітично вилучають метали, зокрема цинк, як за допомогою виносних електролізерів, так i за допомогою електродних блоків, що завантажують у першу непроточну ванну промивання [3]. Недоліком цих способів є те, що осад цинку не $\epsilon$ готовою продукцією через його грубу структуру і забрудненість домішками, що співосаджуються (темне покриття), наслідком чого $є$ необхідність турбот щодо утилізації цинку, який вилучається. Окупити витрати на вилучення металів можливо тільки за їх утилізації безпосередньо в гальванічній лінії у вигляді додаткових шарів металів, які осаджують у додатковій ванні з розведених (для зниження виносу металів) електролітів. Приклад такого нового підходу до вилучення металів у гальванічних лініях запропоновано, наприклад, в [4]. Утилізація металів, що вилучаються, можлива під час виконання як мінімум двох основних умов - стабілізації матеріальних потоків системи промивних ванн і отримання якіс- них шарів металів із розведених електролітів. Перша умова забезпечується електролізом у розведеному електроліті з підтриманням постійної концентрації іонів металів і дозованою подачею води в протитічну схему промивання. Друга умова, що не виконана в розведених електролітах на основі простих солей металів, забезпечується використанням комплексних сполук металів, з яких вони розряджаються 3 більш високими утрудненнями у вигляді компактних дрібнокристалічних опадів.

Мета дослідження - розроблення технологічних схем зниження виносу іонів цинку і нікелю 3 промивними водами гальванічних ліній шляхом електроосадження додаткових шарів металів із розведених комплексних електролітів.

Виклад основного матеріалу. Методика досліджень. Кінетику контактного обміну в системі «цинкове покриття - додатковий шар сплаву» досліджували за допомогою методу Донченко-Антропова [5], що вдосконалений у [6; 7]. Хронопотенціограми і поляризаційні залежності для цього отримували за допомогою потенціостата-гальваностата MTech PGP-550M (http://chem.lnu.edu.ua/mtech/mtech.htm) у триелектродній комірці. Робочі електроди - сталь Ст. 3, цинк, платина 3 покриттям сплавом цинкнікель, сталь із двошаровими покриттями «цинк сплав Zn-Ni»; допоміжний електрод - платиновий; електрод порівняння - хлорид-срібний, з'єднаний iз робочим електролітом за допомогою сольового містка. Значення $\mathrm{pH}$ електролітів контролювали pH-метром СТ-6020A.

Корозійну стійкість покриттів визначали поляризаційним методом у 3 \%-му розчині хлориду натрію.

Зменшення виносу іонів циинку $і$ нікелю шляхом утилізації у вигляді додаткового шару сплаву $\mathrm{Zn}-\mathrm{Ni}$ поверх цинкового покриття. Схему гальванічної лінії цинкування 3 локальним вилученням іонів металів у вигляді додаткового шару покриття представлено на рис. 1. Лінія включає ванну ВЦ для електроосадження основного шару цинкового покриття та систему промивних ванн. Першу, непроточну, ванну ВДШ цієї системи використовують у процесі промивання для електроосадження додаткового шару цинк-нікелевого покриття, яке $є$ більш корозійно стійкім, ніж цинкове покриття. В системі промивних ванн протиточної промивки фінішне промивання проводять в останній ванні промивання ВП з дозованим підживленням чистою водою, а стік забрудненої води - у проточній ванні промивки ВП-С.

3 метою 3'ясування можливості осадження плівок сплавом Zn-Ni на поверхню більш негативного цинку оцінювали наявність контактного витіснення в системі «цинк - електроліт ванни для електроосадження додаткового шару покриття», що містить іони більш позитивного нікелю. Швидкість контактного обміну в ділянці потенціалів реального контактного обміну в цій системі (від -1,04 В до -1,15 В) не перевищує величину $0,2 \mathrm{MA} / \mathrm{cm}^{2}$. При цьому на поверхні 


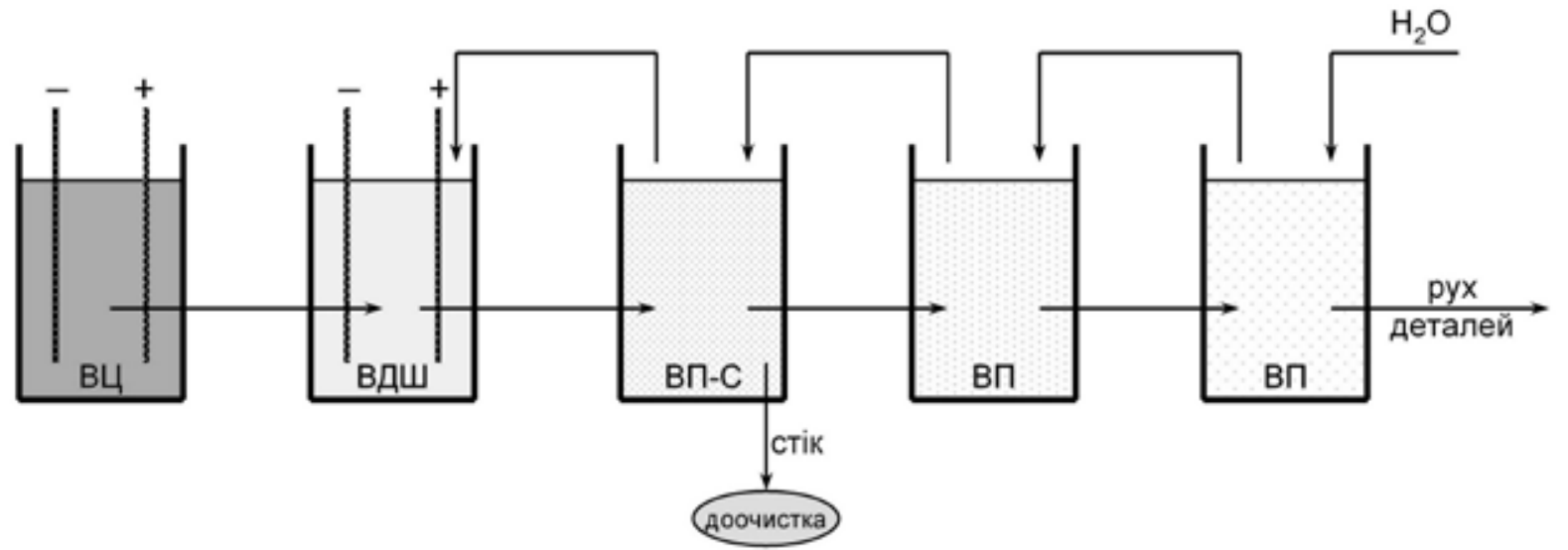

Рис. 1. Схема гальванічної лінї иинкування з вилученням металів, які виносяться у ванни промивання, у вигляді додаткового шару покриття: ВЦ - ванна цинкування; ВДШ - ванна для електроосадження додаткового шару покриття; ВП-С-проточна ванна промивання; ВП-ванна промивання

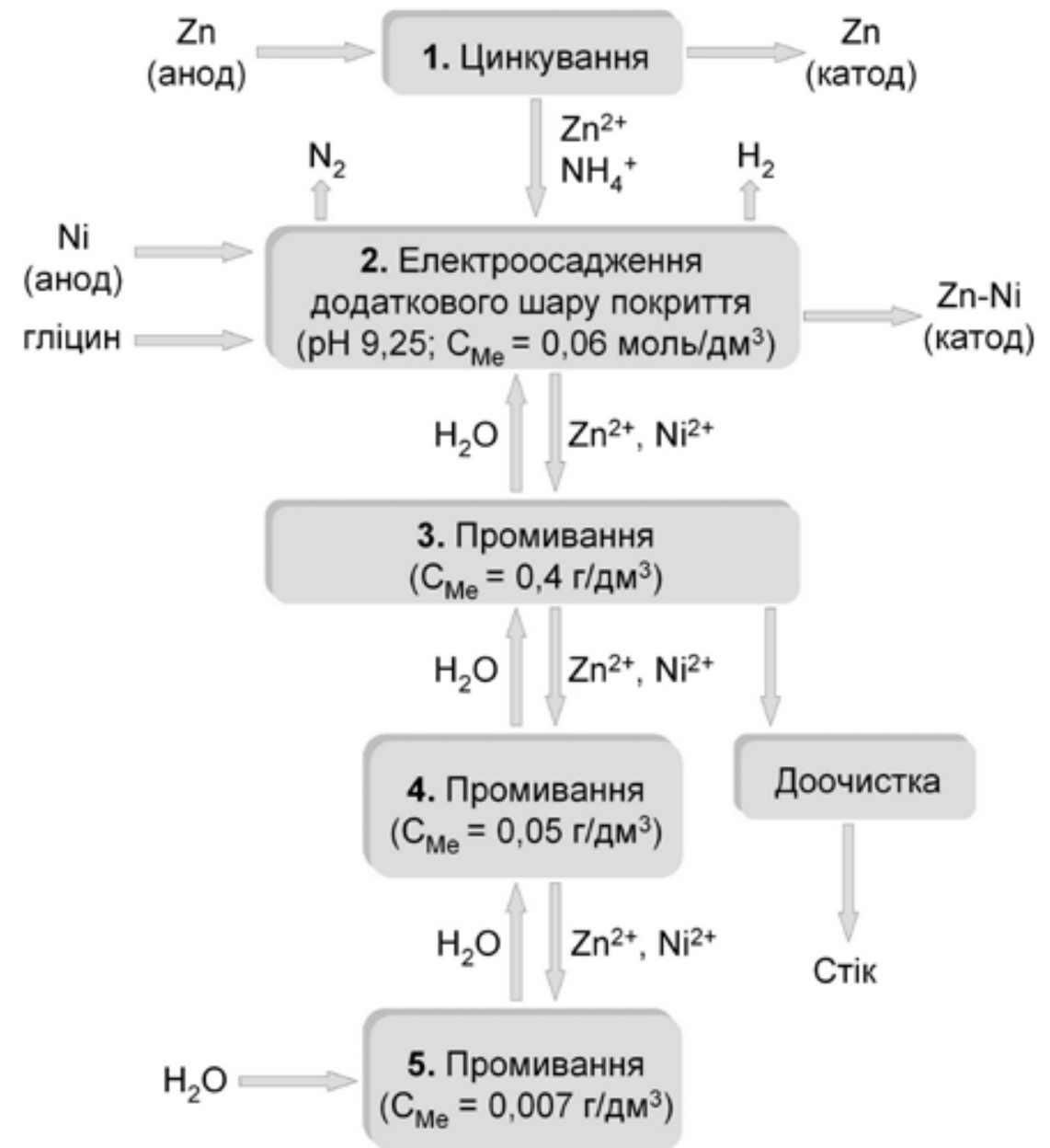

Рис. 2. Технологічні операції в гальванічній лінії цинкування з вилученням металів, які виносяться у ванни промивання, у вигляді додаткового шару покриття

цинку осаджується компактна, добре зчеплена з оцинкованою поверхнею плівка сплаву.

Матеріальний баланс електроліту у ванни цинкування складається 3 надходження іонів цинку в процесі розчинення цинкового аноду, їх вида- лення в процесі відновлення на катоді та виносу кожним квадратним метром поверхні деталей 0,2-0,4 дм³ концентрованого електроліту, що містить, наприклад, іони цинку і амонію, в систему промивних ванн (рис. 2, операція 1). 
Для електроосадження додаткового шару покриття на поверхні (операція 2) оцинкованих деталей використовують першу, непроточну, ванну ВДШ (рис. 1) в системі промивних ванн гальванічної лінії, у якій накопичилося 1-1,5 г/дм³ іонів цинку, що винесений деталями в процесі промивання 3 хлораміакатної ванни цинкування ВЦ. У разі кислого електроліту цинкування в цю ванну додатково вводять 3 г/дм ${ }^{3}$ аміаку, у разі лужного електроліту вводять солі амонію в кількості, що містить 3 г/дм ${ }^{3}$ аміаку. Додають 2-2,5 г/дм 3 іонів нікелю і 28-32 г/дм ${ }^{3}$ гліцину. Доводять рН розчину до величини 9-9,5. 3 такого розведеного за іонами металів електроліту, що містить їхні комплексні сполуки з аміаком і гліцином, на деталі, які промивають, осаджують дрібнокристалічні блискучі плівки сплаву. Для постійного поповнення електроліту іонами нікелю використовують нікелеві аноди в напівпасивному стані, в якому вони розчиняються з обмеженою парціальною швидкістю, за відношення площі поверхні до площі поверхні деталей 1:(3-7). Можливий і більш дешевий варіант поповнення вмісту іонів нікелю - шляхом осаду гідроксиду нікелю, що утворюється під час локальної нейтралізації промивних вод лінії нікелювання. У пасивному стані нікелевий анод використовують як нерозчинний - для окислення надлишку аміаку в електроліті до газоподібного азоту і водню. Час осадження додаткового шару покриття - цинк-нікелевої плівки - залежно від складу електроліту і питомого виносу його деталями за катодної густини струму 20-40 A//2 і накладення перемішування становить 15-40 хвилин.

Після електроосадження плівки сплаву деталі промивають послідовно в останніх ваннах системи промивних ванн (операції 3-5), в яких сумарна концентрація іонів металів поступово зменшується з 0,4 г/дм ${ }^{3}$ до 0,007 г/дм³. Стічну воду, яка утворилася у ванні ВП-С, в якій здійснюється операція 3, залежно від умов на підприємстві, можливо оброблювати локально до досягнення граничнодопустимих концентрацій усіх компонентів електроліту, а можливо направляти на станцію очистки сумарного стоку гальванічного цеху.

Потенціали корозії сталевих зразків із покриттями цинком і додатковим сплавом цинк-нікель свідчать про наявність процесу розчинення цинкового покриття крізь пори покриття сплавом. Проте вже за досить тонких шарів сплаву (0,2-0,6 мкм) спостерігається істотне гальмування цього процесу.

Корозійні діаграми ілюструють істотне зниження струму корозії зразків, цинковий шар яких захищений більш товстим покриттям.

Отже, пропонована технологічна схема [8] дає змогу зменшити винос іонів металів у стік промивних вод гальванічної лінії залежно від складу електроліту цинкування у 3-10 разів (шляхом зменшення концентрації іонів металів у ванні електроосадження додаткового шару, з якої в цій схемі виносяться спо- луки в промивні води порівняно з ванною цинкування) та утилізувати метали у вигляді додаткового шару цинк-нікелевого сплаву на цинковому покритті, що значно підвищує корозійну стійкість поверхні (потенціал корозії $є$ більш позитивним, швидкість корозії зменшується у 1,8-2,2 рази) і, відповідно, збільшує термін експлуатації виробів із таким двошаровим покриттям.

Зменшення виносу іонів цинку $i$ нікелю шляхом утилізації у вигляді підшару сплаву $\mathrm{Zn}-\mathrm{Ni}$ до мультишарового $(\mathrm{Zn}-\mathrm{Ni})_{1} /(\mathrm{Zn}-\mathrm{Ni})_{2}$ покриття. На рис. 3 представлено схему гальванічної лінії для електроосадження мультишарового покриття $(\mathrm{Zn}-\mathrm{Ni})_{1} /(\mathrm{Zn}-\mathrm{Ni})_{2}$. Мультишарове покриття осаджують із пірофосфатно-цитратного електроліту у ванні ВЦН. Покриття послідовно, як і у схемі рис. 1, промивають у системі промивних ванн ВДШ, ВП-С і ВП. Однак, на відміну від схеми рис. 1, на деталі осаджують у ванні ВДШ додатковий шар сплаву $\mathrm{Zn}-\mathrm{Ni}$ не після, а до основного покриття. Для регенерації сполук пірофосфату в схемі додатково передбачено періодичне (у ванні ВДШ) і постійне (у ванні ВП-С) фільтрування розчинів.

Завдяки періодичному вилученню з розчину ванни ВДШ іонів пірофосфату його склад значно відрізняється від складу основного електроліту відношенням концентрації лігандів, пірофосфату і цитрату до концентрації іонів металів, тому для електроосадження додаткового шару сплаву він має й інше значення $\mathrm{pH}$ ( $\mathrm{pH}$ 10,0 - див. операцію 1 на рис. 4). Для вилучення в цій схемі, крім іонів металів, ще й іншого цінного компоненту електроліту для осадження мультишарового покриття - іонів пірофосфату - розчин ванни ВДШ періодично підкислюють до рН 5,5 та отриманий після фільтрування осад, що містіть сполуки $\mathrm{Zn}_{2} \mathrm{P}_{2} \mathrm{O}_{7}$ та $\mathrm{Ni}_{2} \mathrm{P}_{2} \mathrm{O}_{7}$, повертають у ванну для електроосадження мультишарового покриття. Таку ж саму операцію виконують і з розчином проточної ванни промивки ВП-С (операція 4). За дозованого поповнення системи промивних ванн водою у ваннах промивки (операції 4-6) встановлюються ті ж самі концентрації іонів металів, як і у лінії цинкування (рис. 2).

Компактний підшар сплаву, що осаджують у процесі операції 1 на рис. 4, більшою мірою збагачений цинком, ніж мультишарове покриття, а тому має більш негативний потенціал, що розширює асортимент матеріалу деталей для анодного захисту і осадження першого шару без контактного обміну.

Отже, в гальванічній лінії електроосадження мультишарового покриття $(\mathrm{Zn}-\mathrm{Ni})_{1} /(\mathrm{Zn}-\mathrm{Ni})_{2}$ завдяки наявності додаткової ванни з розведеним пірофосфатно-цитратним електролітом на порядок ( 3 0,5 моль/дм³ до 0,06 моль/дм³ ) зменшується винос у систему промивних ванн іонів металів, які утилізуються у вигляді підшару сплаву цинк-нікель.

Головні висновки. Запропоновано технологічні схеми цинкування і електроосадження мультишарових покриттів, що складаються $з$ тонких шарів сплавів 


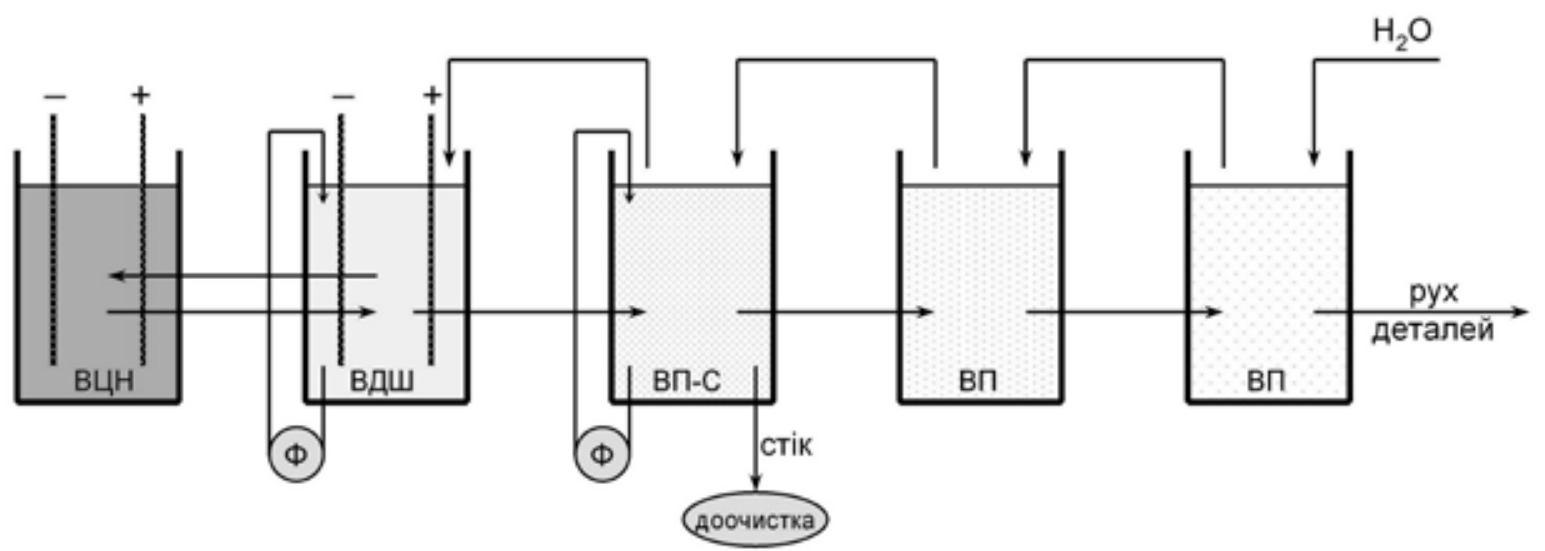

Рис. 3. Схема гальванічної лінії електроосадження мультишарових покриттів (Zn-Ni)1/(Zn-Ni)2 з вилученням металів, які виносяться у ванни промивання, у вигляді підшару: ВЦН - ванна для електроосадження (Zn-Ni)1/(Zn-Ni)2 покриттів; ВДШ - ванна для електроосадження додаткового шару покриття; ВП-С - проточна ванна промивки; ВП - ванна промивки

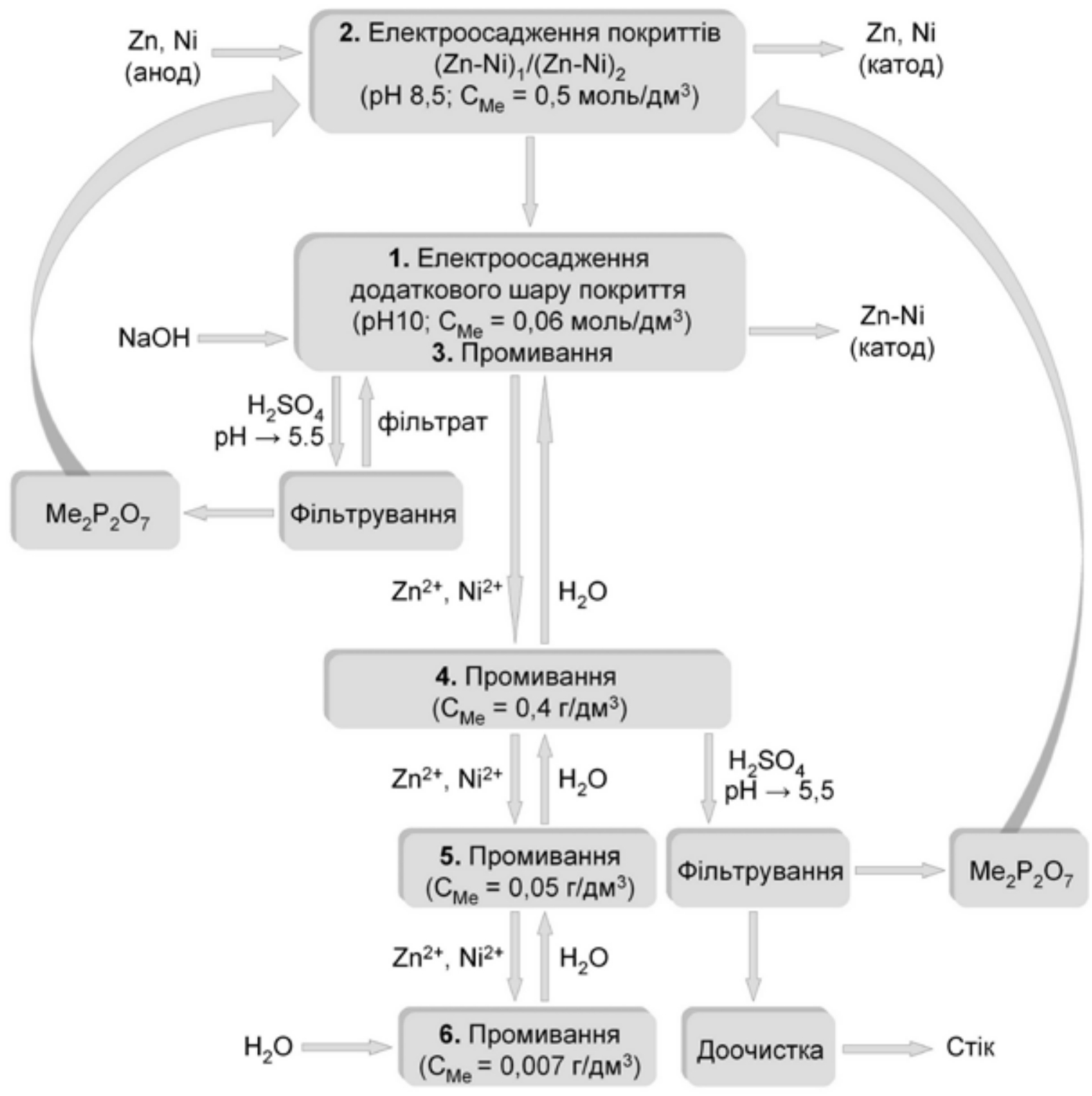

Рис. 4. Технологічні операчії в гальванічній лінії електроосадження мультишарових покриттів (Zn-Ni) $1 /(\mathrm{Zn}-\mathrm{Ni}) 2$ з вилученням металів, які виносяться у ванни промивання, у вигляді підшару 
$\mathrm{Zn}-\mathrm{Ni}$, які містять стадію електроосадження додаткових шарів сплавів із розведених за металами розчинів, завдяки чому на порядок зменшується винос іонів металів у системи промивних ванн. Використання для нанесення додаткових шарів сплаву комплексних гліцинатно-аміакатного і пірофосфатно-цитратного електролітів дає змогу утилізувати іони металів у вигляді компактних якісних шарів сплавів.
Результати дослідження можуть бути використані в гальванічних ділянках і цехах, в яких здійснюється електроосадження цинку з будь-яких електролітів, для позбавлення від операції хроматної пасивації у розчинах, що містять сполуки $\mathrm{Cr}$ (VI), а також на тих підприємствах, де є потреба в захисті сталевої поверхні на рівні кадмієвих покриттів без використання токсичних іонів кадмію.

\section{Література}

1. Гальванотехника : справочное издание / Ф.Ф. Ажогин, М.А. Беленький, И.Е. Галь и др. ; под. ред. А.М. Гимберга. Москва : Металлургия, $1987.736 \mathrm{c}$.

2. Лошкарев Ю.М., Коваленко В.С. Электролитическое цинкование : монография. Днепропетровск : ДДУ, 1994. 224 с.

3. Гибкие автоматизированные гальванические линии : справочник / В.Л. Зубченко и др. ; под общ. ред. В.Л. Зубченко. Москва : Машиностроение, 1989. 672 с.

4. Трубникова Л.В., Байрачный Б.И., Майзелис А.А. Использование первой ступени очистки промывных вод гальванической линии никелирования для нанесения подслоя на обрабатываемые детали. Вода и экология. Проблемы и решения. 2010. № 1, 2. С. 3-11.

5. Донченко М.И., Антропов Л.И. О контактном выделении металлов. Журнал прикладной химии. 1972. Т. 45. Вып. 2. С. 291.

6. Maizelis A.A., Tul'skii G.G., Bairachnyi V.B., Trubnikova L.V. Ehe effect of ligands on contact exchange in the $\mathrm{NdFeB}-\mathrm{Cu}^{2+}-\mathrm{P}_{2} \mathrm{O}_{7}^{4-}-\mathrm{NH}_{4}^{+}$System. Russian Journal of Electrochemistry. 2017. Vol. 53 (4). P. 417-423.

7. Maizelis A.A., Bairachnyi B.I., Tul'skii G.G., A.A. Maizelis. Contact Displacement of Copper at Copper Plating of Carbon Steel Parts. Surface Engineering and Applied Electrochemistry. 2018. Vol. 54. No. 1. P. 12-19.

8. Майзеліс А.О., Артеменко В.М. Спосіб електролітичного вилучення іонів цинку: пат. 123738 Україна: MПК C25D3/22, C25D3/56, C02F1/46. № u20170833; заявл. 11.08.2017; опубл. 12.03.2018, Бюл. № 5. /; заявник та патентовласник НТУ «ХПІ». № 4.4 c. 